http://jmscr.igmpublication.org/home/

ISSN (e)-2347-176x ISSN (p) 2455-0450

crossref DOI: https://dx.doi.org/10.18535/jmscr/v7i7.13

\title{
Isolation, Characterization and Identification of L-Glutaminase, an Anticancer agent Producing Bacteria Occurring in Soil
}

\author{
Authors \\ Dr Praveen Reddy $P^{1 *}$, Ravi $A^{2}$, Gangadhar $N^{3}$, Inna Reddy. $G^{4}$ \\ ${ }^{1}$ Assistant Professor, Department of Microbiology \\ ${ }^{2}$ Lecturer, Department of Biotechnology \\ ${ }^{3}$ Lecturer, Department of Botany \\ Vivekananda Degree and PG College, Karimnagar-505001, Telangana, India \\ ${ }^{4}$ PGT, TS Model School, Ramadugu- 505531, Karimnagar, Telangana, India \\ *Corresponding Author \\ Dr Praveen Reddy.P
}

Department of Microbiology, Vivekananda Degree and PG College, Karimnagar-505001, Telangana, India

\section{Abstract}

Microbes are the sources of various enzymes which are commercially important. Some enzymes, particularly L-glutaminase and L-asparaginase are medically important as they can be used for the treatment of leukemia. Many bacteria reported to produce L-glutaminase which can be used as an anticancer agent. L-glutaminase is used in the preparation of baked foods to increase the flavor of the foods. In the present paper five L-glutaminase producing bacteria were isolated from garden, market area and agricultural soils using minimal L-glutamine medium supplemented with phenol red indicator. Based on microscopic examination and biochemical characterization the bacteria were identified as Pseudomonas, Serratia, Proteus, Staphylococus and Bacillus species. These bacteria can be improved and exploited for the commercial production of L-glutaminase.

Keywords: L-glutaminase, leukemia, anticancer, L-glutaminase producing bacteria.

\section{Introduction}

The L-glutaminase is a hydrolytic cleavage enzyme which cleaves L-glutamine into Lglutamic acid and ammonia. It is produced by a wide range of microbes. It is used in the treatment of acute cancer mainly lymphocytic leukemia. During the treatment it can be used in combination with other drugs or L-asparaginase. L-glutamine is one of the important amino acids required for living cells. It is essential for the preparation of purine and pyrimidine derivates required for the biosynthesis of nucleotides.
Lymphocytic cancer cells lack the enzymatic machinery for the synthesis of L-Glutamine whereas healthy cells are capable of synthesis of L-glutamine. Hence, cancer cells depend upon blood serum for L-glutamine. When Lglutaminase is administered into patient's body it degrades L-glutamine present in serum and makes unavailable to cancer cells. This leads to the death of cancer cells. In addition to medical applications, L-glutaminase is used during the preparation of soy sauce and other fermented foods to increase their flavor. It increases flavor in 
fermented foods by producing L-glutamic acid. It is also used in the estimation of L-glutamine concentration in the microbial culture media and to determine the rate of reaction during threonine synthesis ${ }^{[1,2,3]}$. So far many microbial strains have been reported to produce L-glutaminase. Some of the microbes which are efficient producers of Lglutaminase include E.coli, Pseudomonas sp., Brevibacterium sp., Vibrio costicola, Streptomyces rimosus, Streptomyces avermitilis and Streptomyces griseus ${ }^{4}$. In the present paper L-glutaminase producing bacteria occurring in market area, garden and agricultural soils were isolated and identified till genus level based on microscopic observation and biochemical characterization.

\section{Materials and Methods \\ Soil samples}

Soil samples from garden, market area (located in Karimangar town, Telangana) and agricultural lands (nearby karimnagar town) were collected in sterile polythene bags and stored at $4^{0} \mathrm{C}$ until further use.

\section{Medium for the isolation of L-glutaminase producing bacteria}

Minimal L-glutamine medium was used for the isolation of L-glutaminase producing bacteria. The composition of minimal L-glutamine medium is L-glutamine $-10 \mathrm{~g}, \mathrm{KCl}-0.5 \mathrm{~g}, \mathrm{MgSO}_{4}-0.5$ g, $\mathrm{KH}_{2} \mathrm{PO}_{4}-1.0 \mathrm{~g}, \mathrm{FeSO}_{4}-0.1 \mathrm{~g}, \mathrm{ZnSO}_{4}-0.1 \mathrm{~g}$, $\mathrm{NaCl}-0.5 \mathrm{~g}$, Phenol red $-0.012 \mathrm{~g}$ and distilled water $-1000 \mathrm{ml}$. The $\mathrm{pH}$ of the medium should be adjusted to 6.8. To suppress the growth of fungi $50 \mu \mathrm{g} / \mathrm{ml}$ of nystatin was added. For the preparation of solid medium (minimal Lglutamine agar medium) $20 \mathrm{~g}$ of agar is added. Lglutamine serves as sole carbon and nitrogen source in the medium. Phenol red functions as $\mathrm{pH}$ indicator. In the agar medium L-glutaminase producing bacteria form pink zones around their colonies. In the liquid medium (Minimal Lglutamine broth) L-glutaminase positive bacteria turn the medium colour from yellow to pink.
Serial dilutions of soil samples were prepared from $10^{-1}$ to $10^{-7}$. The minimal L-glutamine agar plates were inoculated with $0.1 \mathrm{ml}$ of $10^{-7}$ dilution of each soil sample and incubated at $37^{\circ} \mathrm{C}$ for 48 hours. The bacterial colonies positive for Lglutaminase production (colonies forming pink zone around them) were isolated and grown as pure cultures. Each bacterial isolate was inoculated into $10 \mathrm{ml}$ of minimal L-glutamine broth and incubated for 48 hours. Unincoulated broth was maintained as control ${ }^{[4,5,6]}$.

\section{Detection of L-glutaminase producing bacteria}

Phenol red is an indicator which exhibits yellow colour in medium at and below 7.0 (in acidic conditions) and pink or red colour in medium with $\mathrm{pH}$ above 7.0 (alkaline conditions). When soil samples are plated on to minimal L-glutamine agar medium the $\mathrm{pH}$ of the medium is 6.8 and medium appears yellow. The bacteria positive Lglutaminase production degrades glutamine and produce L-glutamic acid and ammonia (alkali). This turns medium around their colonies yellow to pink (pink zones) ${ }^{[4]}$. When L-glutaminase positive bacteria are grown in minimal L-glutamine broth the colour of the broth changes from yellow to pink due to accumulation of ammonia (alkali).

\section{Identification of bacteria positive for L- glutaminase production}

Microscopic examination of bacterial isolates was performed after gram staining and endospore staining. In addition, motility test was performed for each bacterial isolate under microscope. Further Indole test, Methyl red test, Voges Proskauer test, Citrate utilization test, Phenyl alanine test, Hydrogen sulfide test, Mannitol salt test, Urease test, Oxidase test, Catalase test, Starch hydrolysis, Gelatin hydrolysis and Casein hydrolysis were performed for all the bacterial isolates positive for L-glutaminase production. Based on microscopic examination and biochemical characterization bacteria were identified till their genus level. 


\section{JMSCR Vol||07||Issue||07||Page 61-65||July}

\section{Results}

Soils samples of garden, market area and agricultural lands were processed using minimal L-glutamine medium supplemented with phenol red indicator to isolate L-glutaminase producing bacteria. Five bacterial isolates were found to be positive for L-glutaminase production. Pink colour zones were formed around their colonies in minimal L-glutamine agar plates. They were designated as $\mathrm{X} 1$ \& $\mathrm{X} 2$ (bacteria isolated from garden soil), Y1 (bacterium isolated from market area soil) and Z1 \& Z2 (bacteria isolated from agricultural soils). When these bacteria were grown in minimal L-glutamine broth supplemented with phenol red indicator the broth colour changed from yellow to pink (Figure -1). The bacteria positive for L-glutaminase production were identified based on microscopic examination (Table-1) and biochemical tests (Table-2) till genus level. X1, X2, Y1, Z1 and Z2 were identified as Pseudomonas, Serratia, Proteus, Staphylococus and Bacillus species respectively.

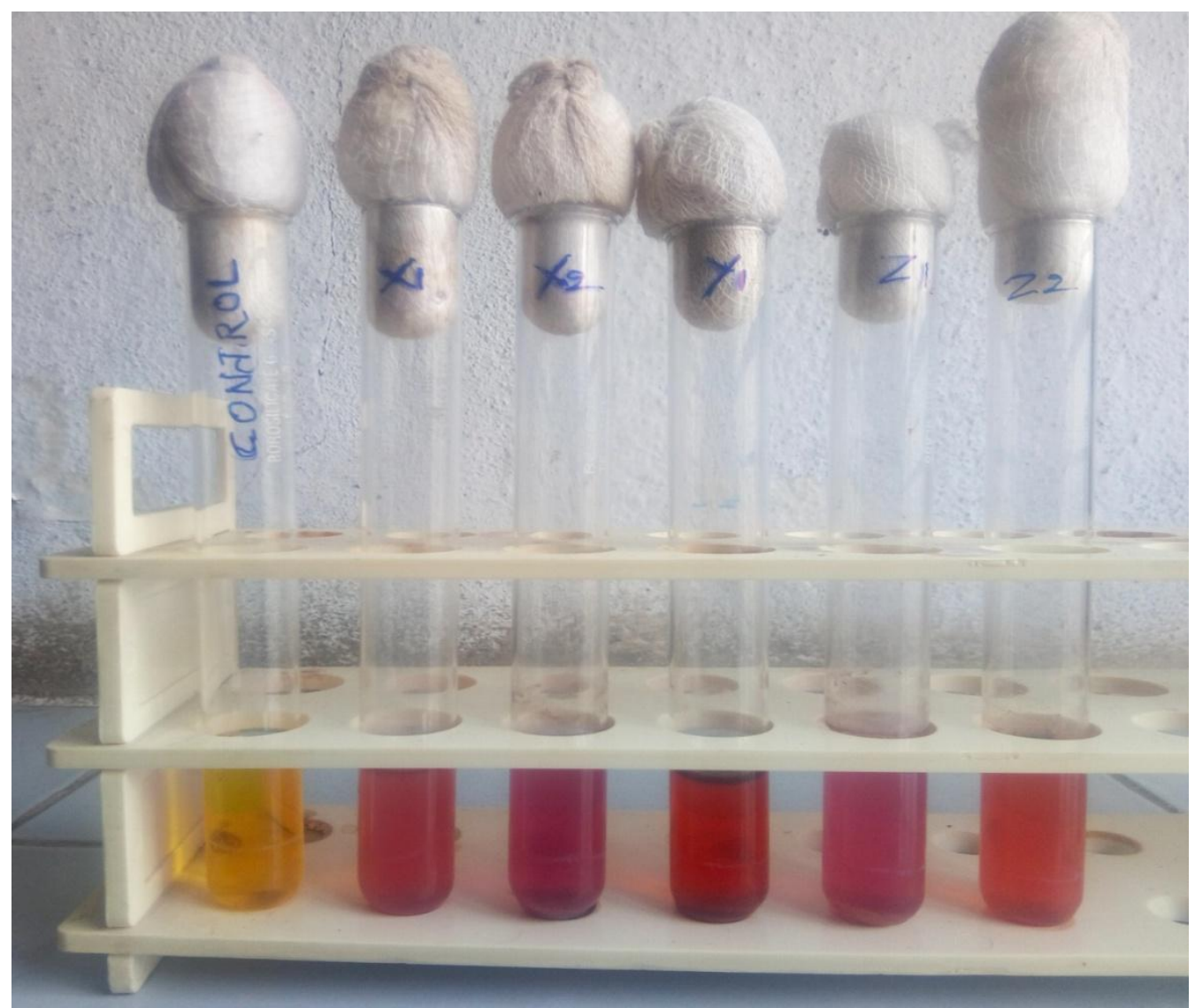

Figure-1: Minimal L-glutamine broth control (yellow) and culture broths positive for L-glutaminase production (pink)

Table-1: Microscopic examination of bacterial isolates

\begin{tabular}{|l|c|c|c|c|}
\hline S.No. & Bacterial isolate & Gram staining & Endospore staining & Motility test \\
\hline 1. & X1 & Gram positive rod & Negative & Positive \\
\hline 2. & X2 & Gram negative rod & Negative & Positive \\
\hline 3. & Y1 & Gram negative rod & Negative & Positive \\
\hline 4. & Z1 & Gram positive coccus & Negative & Negative \\
\hline 5. & Z2 & Gram positive rod & Positive & Positive \\
\hline
\end{tabular}


Table-2: Biochemical Tests of bacterial isolates

\begin{tabular}{|c|c|c|c|c|c|c|c|c|c|c|c|c|c|c|c|}
\hline$\sum_{\dot{\phi}}^{\dot{\theta}}$ & 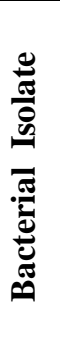 & 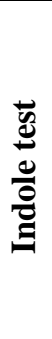 & 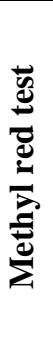 & 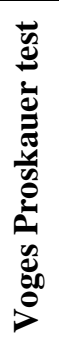 & 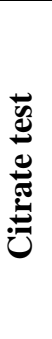 & 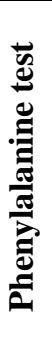 & 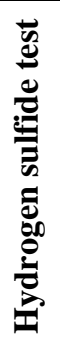 & 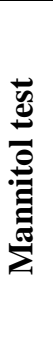 & 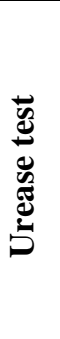 & 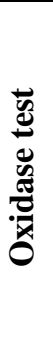 & 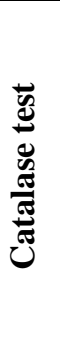 & 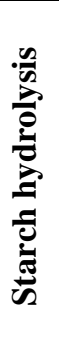 & 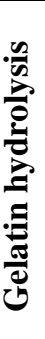 & 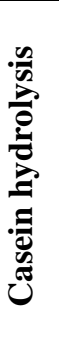 & Bacterium identified \\
\hline 1. & $\mathrm{X} 1$ & - & - & - & + & - & - & - & - & + & + & - & - & + & Pseudomonas \\
\hline 2. & $\mathrm{X} 2$ & - & - & + & + & - & - & + & + & - & + & - & + & + & Serratia \\
\hline 3. & $\mathrm{Y} 1$ & - & + & - & + & + & + & + & + & - & + & - & + & - & Proteus \\
\hline 4. & $\mathrm{Z} 2$ & - & + & + & + & - & - & + & + & - & + & - & + & - & Staphylococcus \\
\hline 5. & $\mathrm{Z3}$ & - & + & - & - & - & - & - & - & - & + & + & + & + & Bacillus \\
\hline
\end{tabular}

\section{Discussion}

Many of the microbial enzymes are exploited commercially. Certain enzymes especially Lglutaminase and L-asparaginase are medically important and significant in the treatment of some cancers. In the present work three soil samples viz., garden, market area and agricultural land are serially diluted and $10^{-7}$ dilution of each soil sample was used as inoculum and plated on minimal L-glutamine agar plates and colonies positive for L-glutaminase production formed pink zones after incubation period. Total five bacterial colonies were positive for L-glutaminase production. Further their ability to produce Lglutaminase was confirmed by growing each bacterial isolate in minimal L-glutamine broth. Five bacterial isolates were identified till their genus level. The bacteria positive for Lglutaminase production were identified as Pseudomonas, Serratia, Proteus, Staphylococus and Bacillus. Gulbahar and Karkaz isolated Lglutaminase producing bacteria from wound infections and identified them as Staphylococcus aureus, Pseudomonas aeruginosa, E.coli and Citrobacter diversus ${ }^{[7]}$. Suresh et al. performed experiments with L-glutaminase producing Serratia marcescens to determine the effect of physical parameters and different nutrients on Lglutaminase production ${ }^{[8]}$. Wade et al., reported L-glutaminase producing Proteus vulgaris ${ }^{[9]}$. Sathish and Prakasham isolated L-glutaminase producing bacterium from Godavari river bank soils of Andhra Pradesh state and identified it as
Bacillus subtilis ${ }^{[10]}$. Similar results were obtained for many researchers.

\section{Conclusion}

In the present study five L-glutaminase producing bacteria were isolated from soil samples of garden, market area and agricultural lands and identified till genus level. Further they can be identified till species level. They can be used to produce L-glutaminase. The conditions for the production of L-glutaminase can be optimized. These bacteria can be genetically improved to enhance the production of L-glutaminase which can be used to treat leukemia.

\section{References}

1. Aravinth VJS, Moklesur RSM, Long CM, Marylin JPS, Ravikumar M, Wong TW. Enhancement of the production of Lglutaminase, an anticancer enzyme, from Aeromonas veronii by adaptive and induced mutation techniques. PLOS ONE. 2017; 12(8): 1-17.

2. Tanti Y, Ekowati C, Usman SFT. Screening and Characterization of Lglutaminase produced by bacteria isolated from Sangihe Talaud Sea. Squalen. 2012; 7(3): 115-122.

3. Savitha SD, Sonal JC, Basavaraj SH. Production, purification and characterization of L-glutaminase from Streptomyces sp. Isolated from soil. 
Journal of Applied Pharmaceutical

Science. 2016; 6(7): 100-105.

4. Rajendra D, Anubrata P, Neha P. Isolation, Production \& Screening of Anti-Cancer enzyme L-glutaminase from Bacillus subtilis. International Journal of Pharmacy and Biological Sciences. 2015; 5(2): 96105.

5. Sridevi S, Prathyusha K, Jagan MYSYV, Sandeep BV. Isolation and primary screening of L-glutaminase from agroresidual wastes. International Journal of Pharmaceutical Sciences Review and Research. 2016; 39(2) 147-150.

6. Swathi S, Vinod KN. Production and characterization of L-glutaminase by Bacillus sp. International Journal of Pharmaceutical Sciences and Research. 2016; 7(4): 1620-1626.

7. Gulbahar FK, Karkaz MT. Determination of L-Glutaminase activity by some bacterial species. International Journal of Current Microbiology and Applied Sciences. 2016; 5(4):218-225.

8. Suresh KS, Muthuvelayudham R, Viruthagiri T. Statistical Optimization based Production of L-Glutaminase (EC.3.5.1.2) by Serratia marcescens under submerged Fermentation. Research Journal of Chemical Sciences. 2013; 3(6): 43-53.

9. Wade HE, Robinson HK, Phillips BW. Asparaginase and Glutaminase Activities of Bacteria. Journal of General Microbiology. 1971; 69: 299-312.

10. Suresh T, Prakasham RS. Isolation and Identification of L-Glutaminase an Antilekeumic enzyme Producing Microorganism From Godavari River Bank Soils in Andhra Pradesh. International Research Journal of Pharmacy. 2010; 1(1): 367-373. 